
QUARTERLY TECHNICAL PROGRESS REPORT NUMBER 21

\title{
THE ECONOMICAL PRODUCTION OF ALCOHOL FUELS FROM COAL-DERIVED SYNTHESIS GAS
}

CONTRACT NO. DE-AC22-91PC91034

REPORTING PERIOD:

October 1, 1996 to December 31, 1996

$$
\text { SUBMITTED TO: }
$$

Document Control Center U.S. Department of Energy

Pittsburgh Energy Technology Center

P.O. Box 10940, MS 921-118

Pittsburgh, PA 15236-0940

\section{SUBMITTED BY:}

West Virginia University Research Corporation on behalf of West Virginia University

617 N. Spruce Street Morgantown, WV 26506

\section{January, 1997}




\section{TABLE OF CONTENTS}

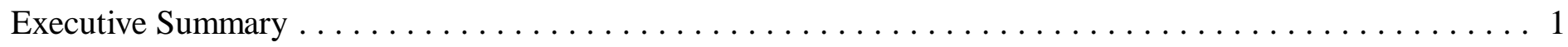

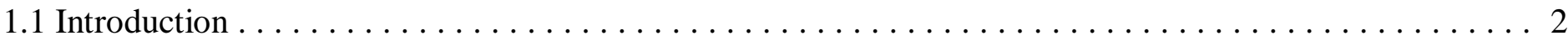

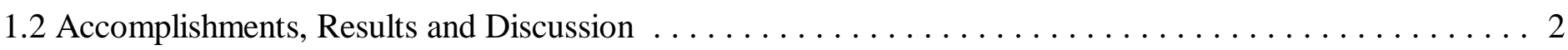

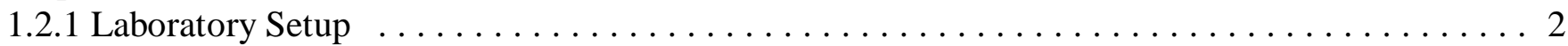

1.2.2 Molybdenum-Based Catalyst Research $\ldots \ldots \ldots \ldots \ldots \ldots \ldots \ldots \ldots \ldots \ldots \ldots \ldots \ldots \ldots \ldots \ldots$

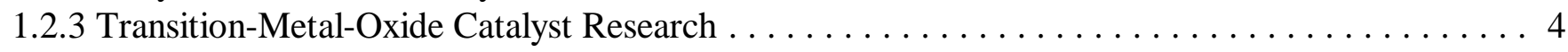

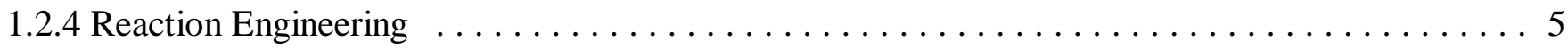

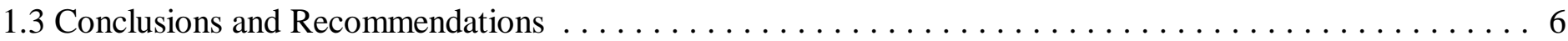

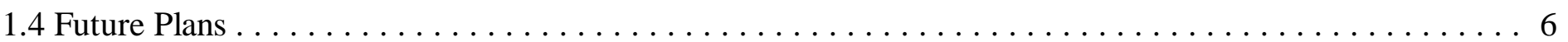




\section{LIST OF TABLES}

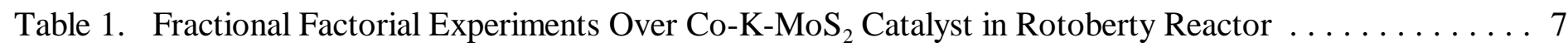

Table 2. Inlet Conditions and Order of Rotoberty Runs $\ldots \ldots \ldots \ldots \ldots \ldots$

Table 3. Product Rates of Formation and Times on Stream for Factorial

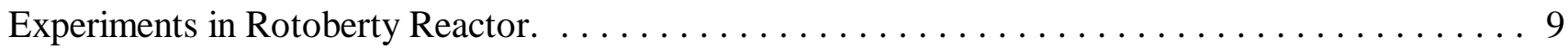

Table 4. Outlet Flow Rates from Rotoberty Reactor. $\ldots \ldots \ldots \ldots \ldots \ldots \ldots \ldots$

Table 5. Outlet Partial Pressures from Rotoberty Reactor $\ldots \ldots \ldots \ldots \ldots \ldots \ldots \ldots \ldots$

Table 6. Comparison of Performance of Packed-Bed

Membrane Reactor $(\mathrm{MR})$ and Packed-Bed Tubular $\ldots \ldots \ldots \ldots \ldots \ldots \ldots \ldots \ldots \ldots \ldots$ 


\section{Executive Summary}

During this time period, at WVU, we tried several methods to eliminate problems related to condensation of heavier products when reduced Mo-Ni-K/C materials were used as catalysts. We then resumed our kinetic study on the reduced Mo-Ni-K/C catalysts. We have also obtained same preliminary results in our attempts to analyze quantitatively the temperature-programmed reduction (TPR) spectra for C-supported Mo-based catalysts. We have completed the kinetic study for the sulfided Co-K-MoS$/ \mathrm{C}$ catalyst. We have compared the results of methanol synthesis using the membrane reactor with those using a simple plug-flow reactor.

At UCC, the complete characterization of selected catalysts has been completed. The results suggest that catalyst pretreatment under different reducing conditions yield different surface compositions and thus different catalytic reactivities. 


\subsection{Introduction}

The objective of Task 1 is to prepare and evaluate catalysts and to develop efficient reactor systems for the selective conversion of hydrogen-lean synthesis gas to alcohol fuel extenders and octane enhancers.

Task 1 is subdivided into three separate subtasks: laboratory and equipment setup; catalysis research; and reaction engineering and modeling. Research at West Virginia University (WVU) is focused on molybdenumbased catalysts for higher alcohol synthesis (HAS). Parallel research carried out at Union Carbide Corporation (UCC) is focused on transition-metal-oxide catalysts.

\subsection{Accomplishments, Results and Discussion}

\subsubsection{Laboratory Setup}

During this reporting period, we needed to eliminate a condensation problem when reduced Mo-Ni-K/C materials were used as catalysts. We first added a hot trap right before the sampling valve in the hope of trapping the very heavy products for separate analysis. Unfortunately, the hot trap did not work well. We then decided to start from a fresh catalyst for each experimental point and to flush the reactor first to make sure no heavy residue presented. We also changed our data processing procedure. After those modifications, we resumed our kinetic study on the reduced Mo-Ni-K/C catalysts.

We purchased a peak-fitting software package, PeakFit from Jandel Scientific, and are now using the software to analyze the TPR spectra previously obtained.

\subsubsection{Molybdenum-Based Catalyst Research}

At WVU, we have obtained final models for HAS kinetics over the Co-K-MoS $/ 2$ catalyst. The experimental data were obtained using a Rotoberty reactor, and are in Tables 1-5. A sequential model for HAS synthesis is used, whereby $\mathrm{MeOH}$ is formed from $\mathrm{CO}$ and $\mathrm{H}_{2}$, then $\mathrm{MeOH}$ forms $\mathrm{EtOH}$, which in turn forms $\mathrm{PrOH}$, etc. All hydrocarbons were modeled as $\mathrm{CH}_{4}$, assumed to be formed from $\mathrm{MeOH}$. The final kinetic equations are of the Langmuir-Hinshelwood (LH) type for gross rates of formation.

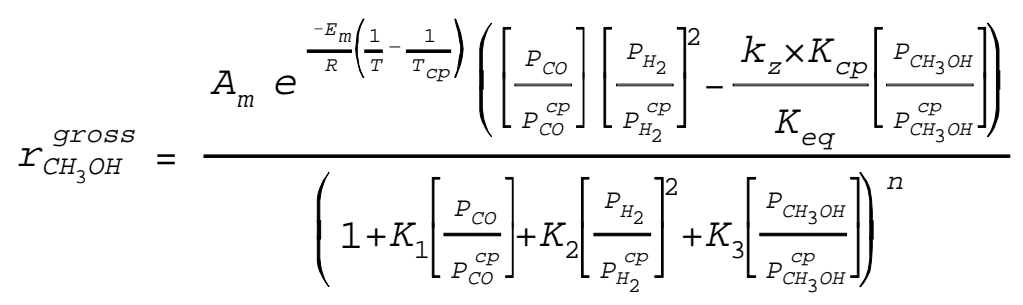

where $K_{C P}=\frac{P_{\mathrm{CH}_{3} \mathrm{OH}}^{C P}}{P_{\mathrm{CO}\left[\mathrm{H}_{2}\right]^{2}}^{C P}{ }^{2}}$ 


$$
\begin{aligned}
& r_{\mathrm{C}_{2} \mathrm{H}_{5} \mathrm{OH}}^{\text {gross }}=\frac{A_{e} e^{\frac{-E_{e}}{R}\left(\frac{1}{T}-\frac{1}{T_{C P}}\right)\left[\frac{P_{\mathrm{CH}_{3} \mathrm{OH}}}{P_{\mathrm{CH}_{3} \mathrm{OH}}^{C P}}\right]}}{1+K\left[\frac{P_{\mathrm{CH}_{3} \mathrm{OH}}}{P_{\mathrm{CH}_{3} \mathrm{OH}}^{\mathrm{CP}}}\right]} \\
& r_{C_{3} \mathrm{H}_{7} \mathrm{OH}}^{\text {grOSS }}=\frac{A_{p} \times e^{\frac{-E_{p}}{R}\left(\frac{1}{T}-\frac{1}{T_{C P}}\right)}\left[\frac{P_{C_{2} \mathrm{H}_{5} \mathrm{OH}}}{P_{C_{2} \mathrm{H}_{5} \mathrm{OH}}^{C P}}\right]}{1+K_{p}\left(\frac{P_{C_{2} \mathrm{H}_{5} \mathrm{OH}}}{P_{C_{2} \mathrm{H}_{5} \mathrm{OH}}^{C P}}\right]} \\
& r_{\mathrm{HC}}^{\text {total }}=\frac{A_{h} \times e^{\frac{-E_{h}}{R}\left(\frac{1}{T}-\frac{1}{T_{\mathrm{CP}}}\right)}\left[\frac{P_{\mathrm{CH}_{3} \mathrm{OH}}}{P_{\mathrm{CH}} \mathrm{OH}}\right]}{1+K_{h}\left(\frac{P_{\mathrm{CH}_{3} \mathrm{OH}}}{P_{\mathrm{CH}_{3} \mathrm{OH}}^{\mathrm{OH}}}\right]}
\end{aligned}
$$

The $\mathrm{LH}$ expression for the gross rate of $\mathrm{MeOH}$ formation includes the reversible reaction, and significant adsorption of $\mathrm{CO}, \mathrm{H}_{2}$ and $\mathrm{MeOH}$. For the $\mathrm{LH}$ expressions for the gross rate of formation of EtOH and total hydrocarbons, only the partial pressure of $\mathrm{MeOH}$ is statistically significant. For the gross rate of formation of $\mathrm{PrOH}$, only the partial pressure of EtOH is statistically significant. The software program DECPOL was used to obtain values of the preexponential factor and activation energy for the rate constants and the equilibrium constants for the adsorbed species. These values are tabulated below for methanol.

$$
\begin{aligned}
& \mathrm{A}_{\mathrm{m}}=4.9047 \mathrm{~mol} / \mathrm{h} / \mathrm{kgcat} \\
& \mathrm{E}_{\mathrm{m}}=117 \mathrm{~kJ} / \mathrm{mol} \\
& \mathrm{k}_{\mathrm{z}}=0.3359 \\
& \mathrm{~K}_{1}=0.0696 \\
& \mathrm{~K}_{2}=0.640 \\
& \mathrm{~K}_{3}=0.694
\end{aligned}
$$

The corresponding values for ethanol are:

$$
\begin{aligned}
& \mathrm{A}_{\mathrm{e}}=1.526 \mathrm{~mol} / \mathrm{h} / \mathrm{kgcat} \\
& \mathrm{E}_{\mathrm{e}}=25.0 \mathrm{~kJ} / \mathrm{mol} \\
& \mathrm{K}_{\mathrm{e}}=0.737
\end{aligned}
$$

Analogously, the values for propanol are:

$$
\begin{aligned}
& \mathrm{A}_{\mathrm{p}}=0.116 \mathrm{~mol} / \mathrm{h} / \mathrm{kgcat} \\
& \mathrm{E}_{\mathrm{p}}=86.8 \mathrm{~kJ} / \mathrm{mol} \\
& \mathrm{K}_{\mathrm{p}}=0.640
\end{aligned}
$$

and those for the hydrocarbons are: 
$\mathrm{A}_{\mathrm{h}}=4.697 \mathrm{~mol} / \mathrm{h} / \mathrm{kgcat}$

$\mathrm{E}_{\mathrm{h}}=95.3 \mathrm{~kJ} / \mathrm{mol}$

$\mathrm{K}_{\mathrm{h}}=1.248$

In the range of conditions used for the $\mathrm{Co}-\mathrm{K}-\mathrm{MoS}_{2} / \mathrm{C}$ catalyst kinetics, the catalyst age and partial pressures of $\mathrm{CO}, \mathrm{H}_{2}$ and inerts are statistically insignificant for $\mathrm{EtOH}, \mathrm{PrOH}$ and total hydrocarbons. This suggests that the chemisorption of alcohol is the rate-limiting step, and that $\mathrm{CO}$-insertion, $\mathrm{H}_{2}$-cleavage, hydrogenation and dehydration steps do not affect the rate correlations under the experimental conditions used.

We are continuing to look at the TPR of the complex reduced Mo catalysts. We have started detailed analyses of the TPR spectra obtained for C-supported Mo-based catalysts, using the Jandel software. Preliminary results suggest that TPR profiles for the Mo/C catalysts can usually be deconvoluted into four peaks. The third peak (located at around $590^{\circ} \mathrm{C}$ ) is most probably from the reduction of impurities in the support, as it is also seen in the case of the $\mathrm{C}$ support alone. The others (located at about $370^{\circ} \mathrm{C}, 460^{\circ} \mathrm{C}$ and $700^{\circ} \mathrm{C}$ respectively) may correspond to the reduction of Mo species on $\mathrm{C}$ support, indicating that the reduction of Mo on $\mathrm{C}$ might consist of several sequential steps. We expect to present more results in the following reports.

As noted above, we are continuing our kinetic study on the reduced Mo-Ni-K/C catalysts. Results and kinetic modeling will be provided in the next reports.

\subsubsection{Transition-Metal-Oxide Catalyst Research}

At UCC, the characterization studies have ended. Ion scattering spectroscopy (ISS) and x-ray photoelectron spectroscopy (XPS) were used to characterize fresh and spent samples of $\mathrm{Zn} / \mathrm{CrO}$ catalyst impregnated with up to $3 \mathrm{wt} \%$ Cs.

An ISS spectrum of the freshly-promoted sample indicates that the catalyst surface contains mostly oxygen and carbon in the outermost atomic layer. $\mathrm{Cr}$ and $\mathrm{Zn}$ are also observable, as well as a feature attributed to charging.

After pretreating with hydrogen, the oxygen appears to have been mostly removed due to the reducing conditions. The primary component of the outermost surface becomes $\mathrm{Cs}$, but $\mathrm{Zn}$ and $\mathrm{Cr}$ are also present as small peaks. Cs appears to migrate to the catalyst surface during the hydrogen pretreatment process. Sputtering with $\mathrm{He}^{+}$indicates that $\mathrm{Zn}$ and some $\mathrm{Cr}$ exist below the top layer, but the $\mathrm{Cs}$ peak becomes relatively small. The $\mathrm{Cl}$ peak is no longer evident, but a diminished $\mathrm{Na}$ peak is still present.

After the catalyst is used in the reactor for about 5 days, Cs and Zn features are present in a ratio not significantly different from the pretreated catalyst. The surface has a large charging feature and a small amount of $\mathrm{Cl}$ present. After sputtering, the $\mathrm{Cs}$ feature is diminished (again indicating a concentration of $\mathrm{Cs}$ near the outermost layer), and the $\mathrm{Zn}$ and $\mathrm{Cr}$ features become more strongly evident. The surface layer of the aged catalyst also contains more $\mathrm{C}$ and $\mathrm{O}$ than the pretreated catalyst.

XPS analysis of the fresh catalyst indicates peaks for $\mathrm{Zn}, \mathrm{Cs}$ and $\mathrm{O}$, with smaller peaks for Cr. Adsorbed 
water, chemisorbed $\mathrm{O}$ and hydroxyl groups are observed. $\mathrm{Zn}$ appears only as $\mathrm{ZnO}$. $\mathrm{Cs}_{2} \mathrm{O}$ is the major form of Cs observed, with minor peaks for $\mathrm{Cs}_{2} \mathrm{Cr}_{2} \mathrm{O}_{7}$ also present. There is trace evidence of $\mathrm{Cr}$ present as $\mathrm{Cr}_{2} \mathrm{O}_{3}$, $\mathrm{Cr}(\mathrm{OH})_{\mathrm{x}}$ and $\mathrm{CrO}_{2}$.

The hydrogen-reduced catalyst also contains $\mathrm{ZnO}$ as the chief chemical state of $\mathrm{Zn}$. The same chemical elements are present, with $\mathrm{Cr}$ appearing to have a somewhat greater concentration. Adsorbed water and chemisorbed oxygen peaks are diminished. The form of the major Cs compound changes during the reduction step. $\mathrm{Cs}_{2} \mathrm{Cr}_{2} \mathrm{O}_{7}$ is the major $\mathrm{Cs}$ peak present, rather than $\mathrm{Cs}_{2} \mathrm{O}$.

The aged catalyst again contains $\mathrm{ZnO}$ as the lone $\mathrm{Zn}$ species. The same elements are present, but less Cs and $\mathrm{Cr}$ appears in the near-surface region. There is increased evidence of charging. $\mathrm{CrO}_{2}$ is the major form of $\mathrm{Cr}$ present. Some $\mathrm{Cs}$ is evident in the form of $\mathrm{Cs}_{2} \mathrm{Cr}_{2} \mathrm{O}_{7}$.

These results suggest that catalyst pre-treatment under different reducing conditions (e.g. pure $\mathrm{H}_{2}$, pure $\mathrm{CO}$, differing $\mathrm{H}_{2} / \mathrm{CO}$ ratios) could yield different surface compositions and thus different catalytic reactivity.

\subsubsection{Reaction Engineering}

The performance of the packed-bed membrane reactor has been evaluated using the BASF methanolsynthesis catalyst. Previously, a quantitative model has been developed incorporating 8 differential equations, one each for the four components, viz., $\mathrm{H}_{2}, \mathrm{CO}, \mathrm{N}_{2}, \mathrm{CH}_{3} \mathrm{OH}$, present on both the shell side and the tube side of the membrane. (Details of the model can be found in MS57). Results from an optimization program yield the favored values of permeability to be used in the model. These values are:

$$
\begin{array}{ll}
\mathcal{P}_{\mathrm{H} 2}=0.2967 & \mathrm{~mol} / \mathrm{min} / \mathrm{m}^{2} / \mathrm{MPa} \\
\mathcal{P}_{\mathrm{CO}}=7.74 & \mathrm{~mol} / \mathrm{min} / \mathrm{m}^{2} / \mathrm{MPa} \\
\mathcal{P}_{\mathrm{N} 2}=8.7 \times 10^{-3} & \mathrm{~mol} / \mathrm{min} / \mathrm{m}^{2} / \mathrm{MPa} \\
\mathcal{P}_{\mathrm{MeOH}}=1.85 & \mathrm{~mol} / \mathrm{min} / \mathrm{m}^{2} / \mathrm{MPa}
\end{array}
$$

The values yield calculated values of conversions which have been compared in MS60 with the actual experimental values from the membrane reactor.

Since the value of the permeance for $\mathrm{CO}$ was so much larger than those for $\mathrm{H}_{2}, \mathrm{~N}_{2}$ or $\mathrm{MeOH}$, we were concerned that the fitting routine might not accurately zero in on the three smaller values. Accordingly, we assumed a model in which the permeance for $\mathrm{CO}$ was set equal to infinity (i.e., CO could move freely between the tube side and the shell side) but the other three components had finite values of permeance. Then we used the optimization routine to calculate those three small values. Those values are:

$$
\begin{array}{ll}
\mathcal{P}_{\mathrm{H} 2}=0.0388 & \mathrm{~mol} / \mathrm{min} / \mathrm{m}^{2} / \mathrm{MPa} \\
\mathcal{P}_{\mathrm{N} 2}=7.12 \times 10^{-4} & \mathrm{~mol} / \mathrm{min} / \mathrm{m}^{2} / \mathrm{MPa} \\
\mathcal{P}_{\mathrm{MeOH}}=1.82 & \mathrm{~mol} / \mathrm{min} / \mathrm{m}^{2} / \mathrm{MPa}
\end{array}
$$

The total error observed in the calculated conversions relative to the experimental conversions with 
Equations (10) was not significantly different from that obtained when Equations (9) were used.

As a final model, we considered one where the permeances for all four components were set equal to infinity (i.e., all components could move freely through the membrane. For all the runs, the experimental values for conversion were at least somewhat higher than the values calculated for this model, and in many instances the difference was significant. Comparing the model of Equations (9) with that of Equations (10) and that of the completely permeable membrane, we believe that the large values obtained in Equations (9) for $\mathrm{CO}$ and $\mathrm{MeOH}$ are significantly different from infinitely large values. Hence the permeances of Equations (9) represent the "best" values to be used for the membrane in our membrane-tube reactor.

The results from the infinite-permeance model also seem to indicate that the membrane reactor should function better than a conventional plug-flow reactor. Of the reaction runs carried out using the membrane-tube reactor, four can be compared (on the basis of total flow rates of reactants, temperature and pressure) with runs carried out using a packed-bed tubular reactor. (Recall that the runs with the packed-bed tubular reactor were carried out in order to obtain an expression for the reaction rate of methanol in terms of the partial pressures and temperature.) The comparison of the conversion of $\mathrm{CO}$ in these four cases can be seen in Table 6. The conversions are not significantly different in three of the four cases, but in the remaining one, a higher value is obtained for the membrane-tube reactor. This case happens to correspond to the lowest total inlet flow rate. Hence it would appear that the membrane-tube reactor is most advantageous when used with a low total flow rate.

\subsection{Conclusions and Recommendations}

Langmuir-Hinshelwood-type kinetic schemes were derived for the formation of methanol through butanol and total hydrocarbons over a Co-K-MoS$/ 2$ catalyst. Reduced Mo-Ni-K/C materials continue to be considered as promising catalysts for HAS. A kinetic study of this catalyst has been started. TPR results on alkali-substituted $\mathrm{Mo} / \mathrm{C}$ are beginning to be amenable to a systematic quantitative analysis. The characterization studies of transition-metal-oxide catalysts has ended. Consideration of various models for the performance of a packed-bed membrane reactor in the synthesis of methanol indicates that a model involving large (but finite) permeances of $\mathrm{CO}$ and $\mathrm{MeOH}$ may be optimal. Comparison of the membrane reactor with a packed-bed tubular reactor indicates that the former may be advantageous at low total flow rates.

\subsection{Future Plans}

We plan to continue the TPR experiments on alkali-substituted carbon-supported Mo-based catalysts, as well as the qualitative and quantitative analyses of the spectra. We are also continuing our kinetic studies on the reduced Mo-Ni-K/C catalysts. 
Table 1. Fractional Factorial Experiments Over Co-K-MoS 2 Catalyst in Rotoberty Reactor

\begin{tabular}{|c||c|c|c|c|c|}
\hline \multirow{2}{*}{$\begin{array}{c}\text { Exp } \\
\text { Label }\end{array}$} & \multirow{2}{*}{$\begin{array}{c}\text { Temp } \\
{ }^{\circ} \mathrm{C}\end{array}$} & \multicolumn{3}{|c|}{ Partial pressures(psi) } & $\begin{array}{c}\text { Concentration } \\
\text { (Mole \%) } \\
\mathrm{CH}_{3} \mathrm{OH}\end{array}$ \\
\cline { 2 - 5 } $\mathrm{A}$ & 300 & 200 & 200 & 200 & 0 \\
\hline \hline $\mathrm{B}$ & 300 & 200 & 200 & 200 & 4 \\
\hline $\mathrm{C}$ & 300 & 200 & 400 & 0 & 0 \\
\hline $\mathrm{D}$ & 300 & 200 & 400 & 0 & 4 \\
\hline $\mathrm{E}$ & 300 & 400 & 200 & 0 & 0 \\
\hline $\mathrm{F}$ & 300 & 400 & 200 & 0 & 4 \\
\hline $\mathrm{G}$ & 300 & 400 & 400 & 200 & 0 \\
\hline $\mathrm{H}$ & 300 & 400 & 400 & 200 & 4 \\
\hline $\mathrm{I}$ & 350 & 200 & 200 & 0 & 0 \\
\hline $\mathrm{J}$ & 350 & 200 & 200 & 0 & 4 \\
\hline $\mathrm{K}$ & 350 & 200 & 400 & 200 & 0 \\
\hline $\mathrm{L}$ & 350 & 200 & 400 & 200 & 4 \\
\hline $\mathrm{M}$ & 350 & 400 & 200 & 200 & 0 \\
\hline $\mathrm{N}$ & 350 & 400 & 200 & 200 & 4 \\
\hline $\mathrm{O}$ & 350 & 400 & 400 & 0 & 0 \\
\hline $\mathrm{P}$ & 350 & 400 & 400 & 0 & 4 \\
\hline $\mathrm{CP}$ & 325 & 300 & 300 & 100 & \\
\hline
\end{tabular}


Table 2. Inlet Conditions and Order of Rotoberty Runs

\begin{tabular}{|c|c|c|c|c|c|c|c|}
\hline \multirow{3}{*}{$\begin{array}{c}\text { Run } \\
\text { No }\end{array}$} & \multirow{3}{*}{$\begin{array}{l}\text { Expt } \\
\text { label }\end{array}$} & \multirow{3}{*}{$\begin{array}{c}\text { Temp } \\
(\mathbf{K})\end{array}$} & \multirow{3}{*}{$\begin{array}{c}\text { Pressure } \\
\text { (Psig) }\end{array}$} & \multicolumn{4}{|c|}{ Inlet Flow Rates } \\
\hline & & & & \multicolumn{3}{|c|}{ Gas (cc NTP/min) } & \multirow{2}{*}{$\begin{array}{c}\text { Liqd (cc/min) } \\
\mathrm{CH}_{3} \mathrm{OH} \\
\end{array}$} \\
\hline & & & & $\mathrm{CO}$ & $\mathbf{H}_{2}$ & $\mathrm{He}$ & \\
\hline 1 & $\mathrm{CP}$ & 598 & 700.00 & 128.50 & 128.50 & 43.00 & 0.01 \\
\hline 2 & $\mathrm{O}$ & 623 & 800.00 & 150.00 & 150.00 & 0.00 & 0.00 \\
\hline 3 & $\mathrm{P}$ & 623 & 800.00 & 150.00 & 150.00 & 0.00 & 0.02 \\
\hline 4 & $\mathrm{~B}$ & 573 & 600.00 & 100.00 & 100.00 & 100.00 & 0.02 \\
\hline 5 & I & 623 & 400.00 & 150.00 & 150.00 & 0.00 & 0.00 \\
\hline 6 & $\mathrm{CP}$ & 598 & 700.00 & 128.50 & 128.50 & 43.00 & 0.01 \\
\hline 7 & K & 623 & 800.00 & 150.00 & 75.00 & 75.00 & 0.00 \\
\hline 8 & M & 623 & 800.00 & 75.00 & 150.00 & 75.00 & 0.00 \\
\hline 9 & $\mathrm{CP}$ & 598 & 700.00 & 128.50 & 128.50 & 43.00 & 0.01 \\
\hline 10 & $\mathrm{~N}$ & 623 & 800.00 & 75.00 & 150.00 & 75.00 & 0.02 \\
\hline 11 & $\mathrm{C}$ & 573 & 600.00 & 200.00 & 100.00 & 0.00 & 0.00 \\
\hline 12 & $\mathrm{D}$ & 573 & 600.00 & 200.00 & 100.00 & 0.00 & 0.02 \\
\hline 13 & A & 573 & 600.00 & 100.00 & 100.00 & 100.00 & 0.00 \\
\hline 14 & $\mathrm{CP}$ & 598 & 700.00 & 128.50 & 128.50 & 43.00 & 0.01 \\
\hline 15 & $\mathrm{~L}$ & 623 & 800.00 & 150.00 & 75.00 & 75.00 & 0.02 \\
\hline 16 & $\mathrm{~J}$ & 623 & 400.00 & 150.00 & 150.00 & 0.00 & 0.02 \\
\hline 17 & $\mathrm{H}$ & 573 & 1000.00 & 120.00 & 120.00 & 60.00 & 0.02 \\
\hline 18 & G & 573 & 1000.00 & 120.00 & 120.00 & 60.00 & 0.00 \\
\hline 19 & F & 573 & 600.00 & 100.00 & 200.00 & 0.00 & 0.02 \\
\hline 20 & E & 573 & 600.00 & 100.00 & 200.00 & 0.00 & 0.00 \\
\hline 21 & $\mathrm{CP}$ & 598 & 700.00 & 128.50 & 128.50 & 43.00 & 0.01 \\
\hline
\end{tabular}


Table 3. Product Rates of Formation and Times on Stream for Factorial Experiments in Rotoberty Reactor.

\begin{tabular}{|c|c|c|c|c|c|c|}
\hline \multirow{2}{*}{$\begin{array}{c}\text { Run } \\
\text { No }\end{array}$} & \multirow{2}{*}{$\begin{array}{c}\text { Expt } \\
\text { Label }\end{array}$} & \multicolumn{4}{|c|}{ Product rates of formation (g/h/kg-cat) } & \multirow{2}{*}{$\begin{array}{c}\text { Time on } \\
\text { Stream } \\
\text { (h) }\end{array}$} \\
\hline & & Hydrocarbons & Methanol & Ethanol & Propanol & \\
\hline 1 & $\mathrm{CP}$ & 40.96 & -79.23 & 40.00 & 5.52 & 12.00 \\
\hline 2 & $\mathrm{O}$ & 43.09 & 50.86 & 26.60 & 6.03 & 25.50 \\
\hline 3 & $\mathrm{P}$ & 94.04 & -241.21 & 72.12 & 11.66 & 34.50 \\
\hline 4 & $\mathrm{~B}$ & 21.11 & -97.98 & 44.24 & 1.14 & 55.50 \\
\hline 5 & I & 21.69 & 34.95 & 11.95 & 1.84 & 69.00 \\
\hline 6 & $\mathrm{CP}$ & 27.72 & -70.22 & 40.34 & 5.08 & 79.50 \\
\hline 7 & $\mathrm{~K}$ & 23.36 & 20.95 & 11.43 & 2.76 & 91.50 \\
\hline 8 & $\mathrm{M}$ & 13.41 & 21.23 & 7.55 & 1.39 & 103.50 \\
\hline 9 & $\mathrm{CP}$ & 43.67 & -83.60 & 37.92 & 5.20 & 12.00 \\
\hline 10 & $\mathrm{~N}$ & 83.45 & -237.82 & 43.03 & 8.59 & 27.00 \\
\hline 11 & $\mathrm{C}$ & 2.49 & 9.78 & 4.18 & 0.59 & 37.50 \\
\hline 12 & $\mathrm{D}$ & 18.41 & -100.19 & 36.59 & 1.52 & 49.50 \\
\hline 13 & $\mathrm{~A}$ & 3.49 & 16.00 & 4.98 & 0.75 & 61.50 \\
\hline 14 & $\mathrm{CP}$ & 27.90 & -70.14 & 36.31 & 4.53 & 73.50 \\
\hline 15 & $\mathrm{~L}$ & 87.12 & -286.84 & 49.58 & 12.79 & 84.00 \\
\hline 16 & $\mathrm{~J}$ & 67.67 & -195.69 & 41.22 & 6.79 & 97.50 \\
\hline 17 & $\mathrm{H}$ & 25.41 & -89.15 & 63.21 & 1.13 & 113.00 \\
\hline 18 & $\mathrm{G}$ & 0.46 & 3.29 & 0.96 & 0.10 & 122.00 \\
\hline 19 & $\mathrm{~F}$ & 16.73 & -55.99 & 47.11 & 0.57 & 131.00 \\
\hline 20 & $\mathrm{E}$ & 0.96 & 11.33 & 1.96 & 0.15 & 140.00 \\
\hline 21 & $\mathrm{CP}$ & 26.90 & -46.56 & 34.47 & 4.31 & 149.00 \\
\hline
\end{tabular}




\begin{tabular}{|c|c|c|c|c|c|c|c|c|c|c|c|c|c|c|c|c|c|c|c|c|c|c|}
\hline \multirow{9}{*}{ 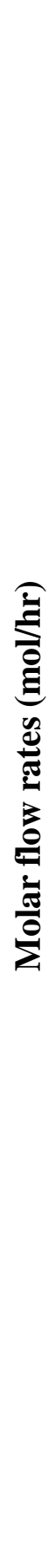 } & 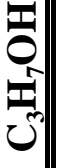 & 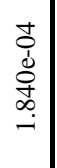 & 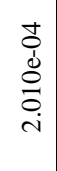 & 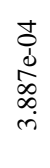 & 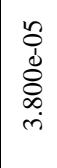 & 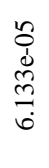 & 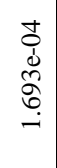 & 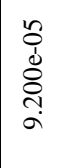 & 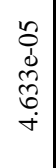 & 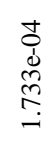 & 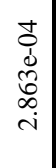 & 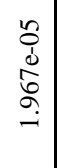 & $\begin{array}{l}n \\
\vdots \\
\vdots \\
o \\
o \\
i n\end{array}$ & 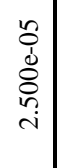 & 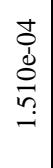 & $\begin{array}{l}\text { ț } \\
\stackrel{d}{j} \\
\stackrel{0}{0} \\
\stackrel{+}{+}\end{array}$ & 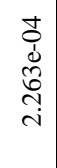 & $\begin{array}{l}n \\
0 \\
\dot{j} \\
b \\
\stackrel{0}{n} \\
\dot{n}\end{array}$ & $\begin{array}{l}\stackrel{8}{0} \\
\dot{j} \\
m \\
m \\
m\end{array}$ & 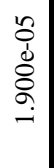 & 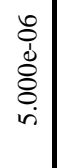 & 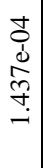 \\
\hline & 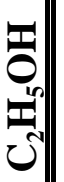 & 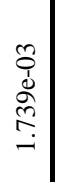 & 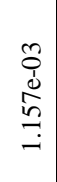 & 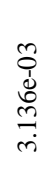 & 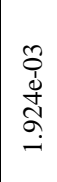 & 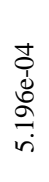 & 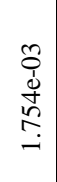 & 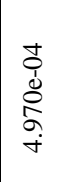 & 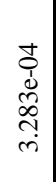 & 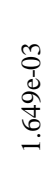 & 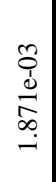 & 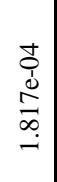 & 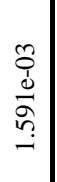 & 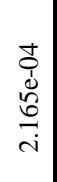 & 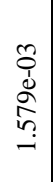 & 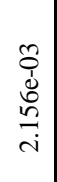 & 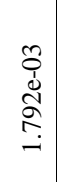 & $\begin{array}{l}\tilde{O} \\
\dot{d} \\
\infty \\
\stackrel{\leftrightarrow}{+} \\
i\end{array}$ & $\begin{array}{l}n \\
\vdots \\
\dot{j} \\
\stackrel{+}{+} \\
\dot{+}\end{array}$ & 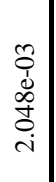 & 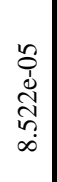 & 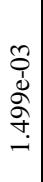 \\
\hline & 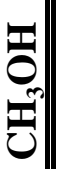 & $\begin{array}{l}0 \\
0 \\
0 \\
0 \\
\infty \\
0 \\
0\end{array}$ & 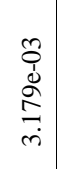 & 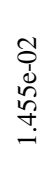 & 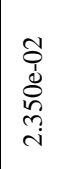 & 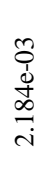 & 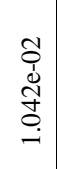 & 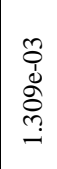 & 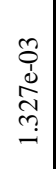 & 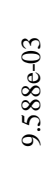 & $\begin{array}{l}\mathfrak{o} \\
\grave{d} \\
\stackrel{d}{0} \\
\stackrel{+}{-}\end{array}$ & 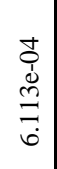 & 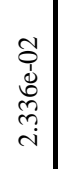 & 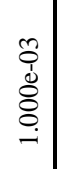 & $\begin{array}{l}\text { Õ } \\
\dot{D} \\
\stackrel{0}{0} \\
\stackrel{0}{-}\end{array}$ & 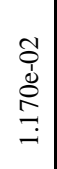 & $\begin{array}{l}\stackrel{d}{0} \\
\dot{d} \\
\stackrel{\Omega}{.} \\
\stackrel{-}{-}\end{array}$ & 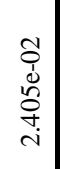 & $\begin{array}{l}t \\
0 \\
d \\
b \\
b \\
i \\
i\end{array}$ & 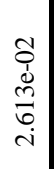 & 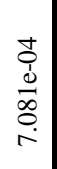 & 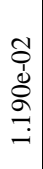 \\
\hline & 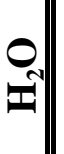 & 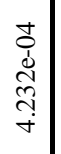 & 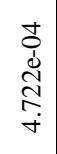 & 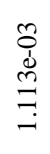 & 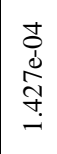 & 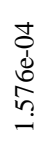 & 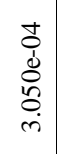 & $\begin{array}{l}\text { ț } \\
\vdots \\
0 \\
0 \\
\vdots \\
-\end{array}$ & 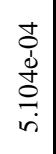 & $\begin{array}{l}\text { ț } \\
\dot{d} \\
\dot{o} \\
\dot{\sigma} \\
\dot{r}\end{array}$ & 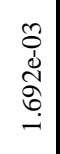 & 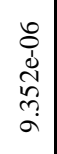 & 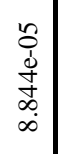 & $\begin{array}{l}0 \\
\vdots \\
\stackrel{N}{N} \\
\hat{\sigma} \\
-\end{array}$ & 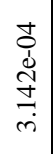 & 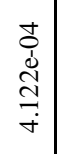 & 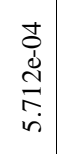 & 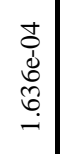 & 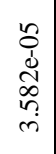 & 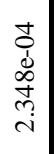 & 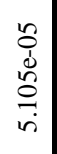 & $\begin{array}{l}\frac{t}{d} \\
\dot{d} \\
\vec{t} \\
i \\
i\end{array}$ \\
\hline & $\stackrel{\oplus}{\Perp}$ & 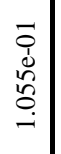 & $\begin{array}{l}8 \\
8 \\
+ \\
0 \\
0 \\
0 \\
0\end{array}$ & $\begin{array}{l}8 \\
\text { o } \\
+ \\
8 \\
8 \\
0\end{array}$ & 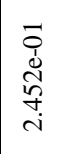 & $\begin{array}{l}8 \\
0 \\
+ \\
8 \\
8 \\
0 \\
0\end{array}$ & $\begin{array}{l}\overrightarrow{0} \\
\vdots \\
\tilde{\delta} \\
0 \\
0 \\
-\end{array}$ & $\begin{array}{l}\vec{j} \\
\dot{d} \\
\widehat{\infty} \\
\stackrel{-}{-}\end{array}$ & 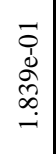 & 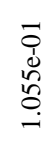 & 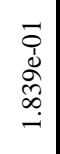 & $\begin{array}{l}8 \\
8 \\
+ \\
8 \\
\vdots \\
0\end{array}$ & $\begin{array}{l}8 \\
8 \\
+ \\
8 \\
8 \\
0\end{array}$ & 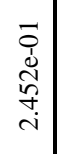 & 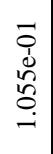 & $\begin{array}{l}\vec{j} \\
\vdots \\
0 \\
\infty \\
- \\
-\end{array}$ & $\begin{array}{l}8 \\
8 \\
+ \\
8 \\
0 \\
0\end{array}$ & 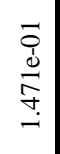 & 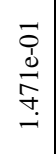 & $\begin{array}{l}8 \\
0 \\
+ \\
0 \\
0 \\
0 \\
0\end{array}$ & $\begin{array}{l}8 \\
0 \\
+ \\
\$ \\
\vdots \\
0\end{array}$ & 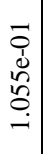 \\
\hline & $\mathbf{Z}^{N}$ & 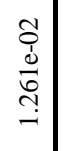 & 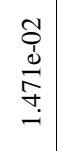 & 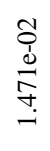 & $\begin{array}{l}\tilde{O} \\
\dot{d} \\
\stackrel{0}{0} \\
\dot{0} \\
\dot{0}\end{array}$ & 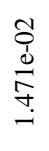 & 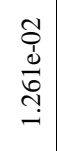 & 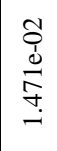 & $\begin{array}{c}m \\
\stackrel{0}{j} \\
\stackrel{j}{n} \\
m \\
r\end{array}$ & 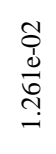 & 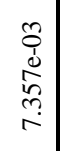 & 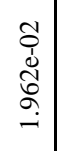 & 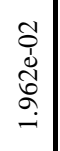 & $\begin{array}{c}0 \\
\dot{d} \\
\dot{d} \\
o \\
\infty \\
\sigma\end{array}$ & $\begin{array}{l}\widetilde{O} \\
\dot{j} \\
\stackrel{0}{0} \\
\stackrel{\sim}{-}\end{array}$ & 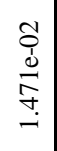 & 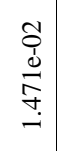 & 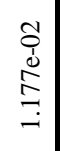 & 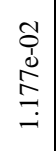 & 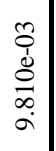 & 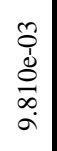 & 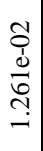 \\
\hline & $\mathbf{I}^{\mathbf{2}}$ & $\begin{array}{l}\overrightarrow{0} \\
\dot{d} \\
\dot{0} \\
\dot{i} \\
i\end{array}$ & 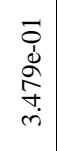 & 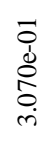 & $\begin{array}{l}\overline{0} \\
\dot{d} \\
\dot{0} \\
\stackrel{0}{-} \\
-\end{array}$ & $\begin{array}{l}\bar{o} \\
\stackrel{d}{d} \\
\hat{n} \\
\dot{n}\end{array}$ & $\begin{array}{l}\overline{0} \\
\vdots \\
0 \\
0 \\
i \\
i\end{array}$ & $\begin{array}{l}\bar{S} \\
\dot{j} \\
\stackrel{+}{+} \\
\stackrel{-}{-}\end{array}$ & $\begin{array}{l}\overline{0} \\
\dot{0} \\
0 \\
0 \\
\dot{0} \\
\dot{r}\end{array}$ & $\begin{array}{l}\overline{0} \\
\vdots \\
\hat{0} \\
0 \\
i \\
i\end{array}$ & $\begin{array}{c}\bar{c} \\
\dot{d} \\
\stackrel{0}{\sim} \\
\vec{m}\end{array}$ & $\begin{array}{l}\bar{c} \\
\dot{d} \\
\stackrel{i}{+} \\
\text { ì }\end{array}$ & $\begin{array}{l}\overrightarrow{0} \\
\stackrel{d}{\mathbf{N}} \\
\hat{\infty} \\
- \\
-\end{array}$ & 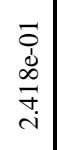 & $\begin{array}{l}\overline{0} \\
\dot{d} \\
0 \\
0 \\
i\end{array}$ & $\begin{array}{l}\overrightarrow{\bar{d}} \\
\stackrel{0}{0} \\
\stackrel{m}{-}\end{array}$ & $\begin{array}{l}\overrightarrow{\bar{O}} \\
\stackrel{\dot{d}}{\vec{T}} \\
\stackrel{m}{m}\end{array}$ & $\begin{array}{l}\vec{i} \\
\stackrel{d}{\vec{j}} \\
\vec{j} \\
\vec{i}\end{array}$ & 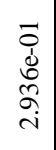 & 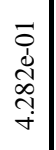 & $\begin{array}{l}\overline{0} \\
\grave{d} \\
\infty \\
\infty \\
\dot{+}\end{array}$ & 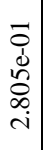 \\
\hline & || & $\begin{array}{c}\stackrel{1}{0} \\
\stackrel{0}{d} \\
\stackrel{\infty}{=} \\
=\end{array}$ & 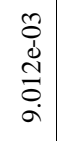 & 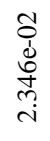 & 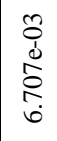 & 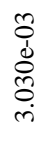 & 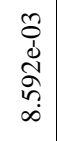 & $\begin{array}{c}\stackrel{r}{o} \\
\stackrel{d}{n} \\
\tilde{r} \\
\dot{r}\end{array}$ & $\begin{array}{l}\stackrel{2}{0} \\
d \\
\dot{d} \\
\stackrel{+}{+} \\
\stackrel{+}{+}\end{array}$ & 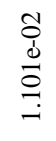 & 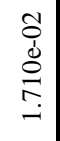 & $\begin{array}{l}\text { ț } \\
\vdots \\
\vdots \\
\delta \\
o \\
0\end{array}$ & 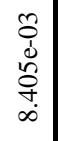 & 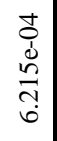 & $\begin{array}{l}\tilde{\rho} \\
\dot{j} \\
\dot{j} \\
\infty \\
\infty \\
\infty\end{array}$ & $\begin{array}{l}\overparen{O} \\
d \\
d \\
o \\
0 \\
i \\
i\end{array}$ & 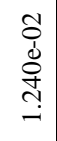 & 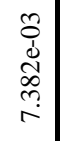 & 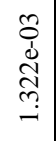 & 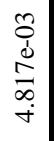 & 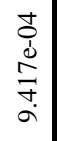 & 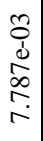 \\
\hline & ○ी| & $\begin{array}{l}\overrightarrow{0} \\
\dot{j} \\
0 \\
0 \\
0 \\
i\end{array}$ & $\begin{array}{l}\overrightarrow{0} \\
\dot{d} \\
\hat{\sim} \\
\tilde{c} \\
\dot{n}\end{array}$ & 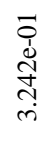 & 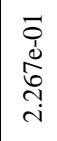 & $\begin{array}{l}\bar{o} \\
\dot{d} \\
\dot{o} \\
\dot{J} \\
\dot{m}\end{array}$ & 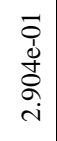 & $\begin{array}{c}\bar{o} \\
\dot{d} \\
\tilde{m} \\
\dot{f} \\
\dot{m}\end{array}$ & $\begin{array}{l}\overrightarrow{0} \\
\stackrel{d}{d} \\
\stackrel{0}{o} \\
\stackrel{-}{-}\end{array}$ & $\begin{array}{l}\overrightarrow{0} \\
\dot{d} \\
\infty \\
\infty \\
\infty \\
i\end{array}$ & $\begin{array}{l}\overrightarrow{0} \\
\dot{\jmath} \\
\stackrel{0}{0} \\
\stackrel{n}{\rightarrow} \\
-\end{array}$ & $\begin{array}{l}\overrightarrow{0} \\
\dot{d} \\
\stackrel{0}{0} \\
\dot{+} \\
\dot{+}\end{array}$ & $\begin{array}{l}\overrightarrow{0} \\
\dot{d} \\
\overrightarrow{0} \\
\dot{+} \\
\dot{+}\end{array}$ & 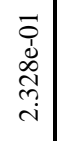 & 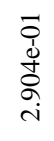 & $\begin{array}{l}\overrightarrow{0} \\
\stackrel{j}{~} \\
\vec{\jmath} \\
\vec{n}\end{array}$ & $\begin{array}{l}\bar{\sigma} \\
\dot{d} \\
\tilde{\sigma} \\
\stackrel{m}{m}\end{array}$ & $\begin{array}{l}\overrightarrow{0} \\
\dot{\jmath} \\
\stackrel{n}{\vec{n}} \\
\vec{i}\end{array}$ & $\begin{array}{l}\overrightarrow{0} \\
\dot{d} \\
\infty \\
\infty \\
i \\
i\end{array}$ & 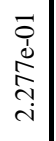 & 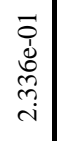 & $\begin{array}{l}\overrightarrow{0} \\
\dot{j} \\
\grave{\vdots} \\
\dot{i}\end{array}$ \\
\hline$\vec{a}$ & & 8 & 0 & $a$ & $\infty$ & - & $\tilde{z}$ & 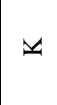 & $\Sigma$ & ठิ & $\mathrm{z}$ & $u$ & 0 & $\varangle$ & 己े & \lrcorner & - & 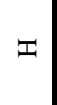 & 0 & 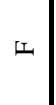 & $\Phi$ & $\ddot{z}$ \\
\hline$\Xi$ & & -1 & $N$ & $m$ & $\theta$ & $n$ & 0 & $r$ & $\infty$ & $a$ & $\stackrel{\circ}{=}$ & $=$ & $\simeq$ & $\stackrel{m}{\sim}$ & \pm & 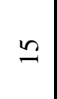 & $\stackrel{0}{0}$ & $=$ & $\stackrel{\infty}{\sim}$ & 2 & $\stackrel{\sim}{)}$ & $\vec{N}$ \\
\hline
\end{tabular}




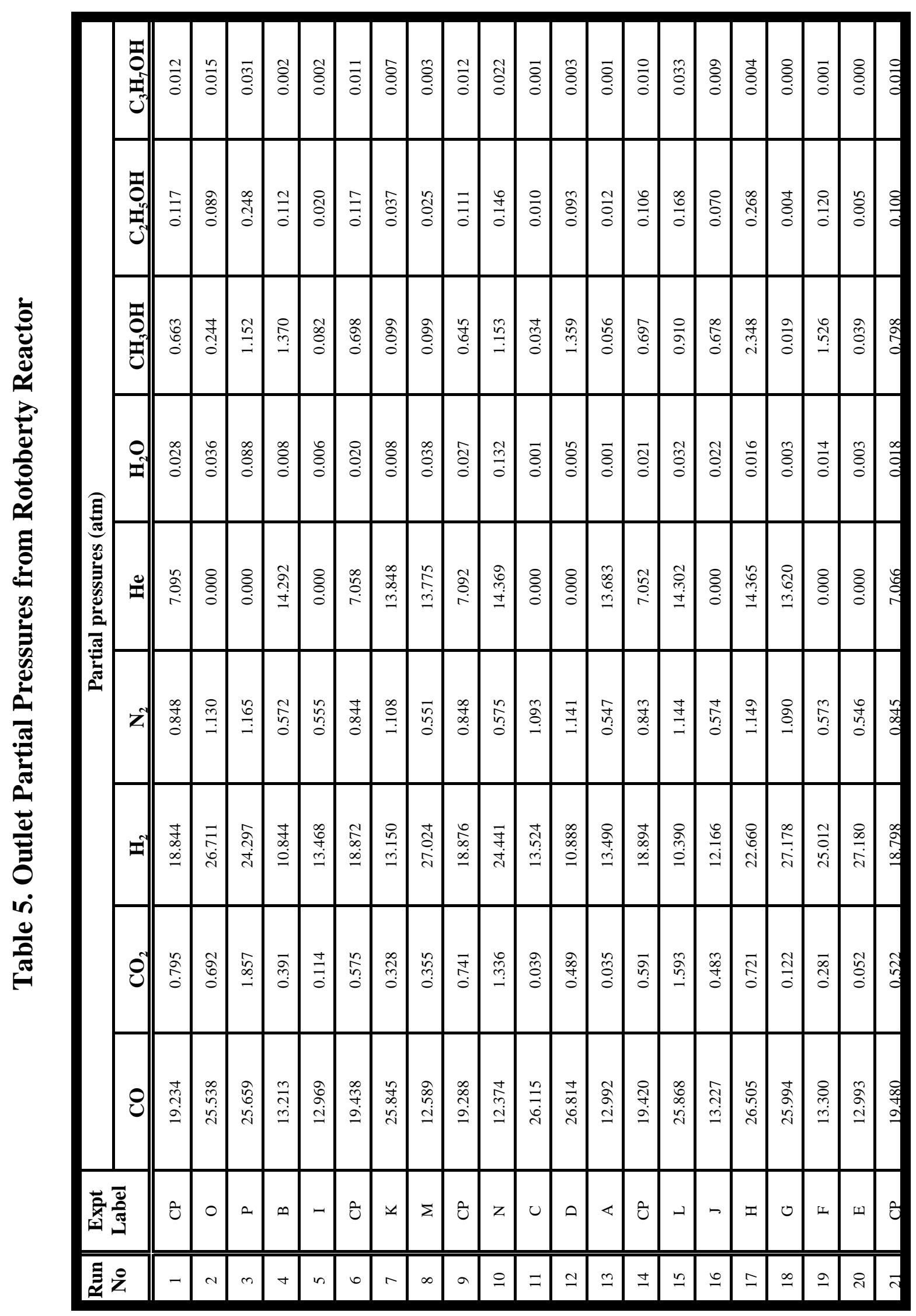




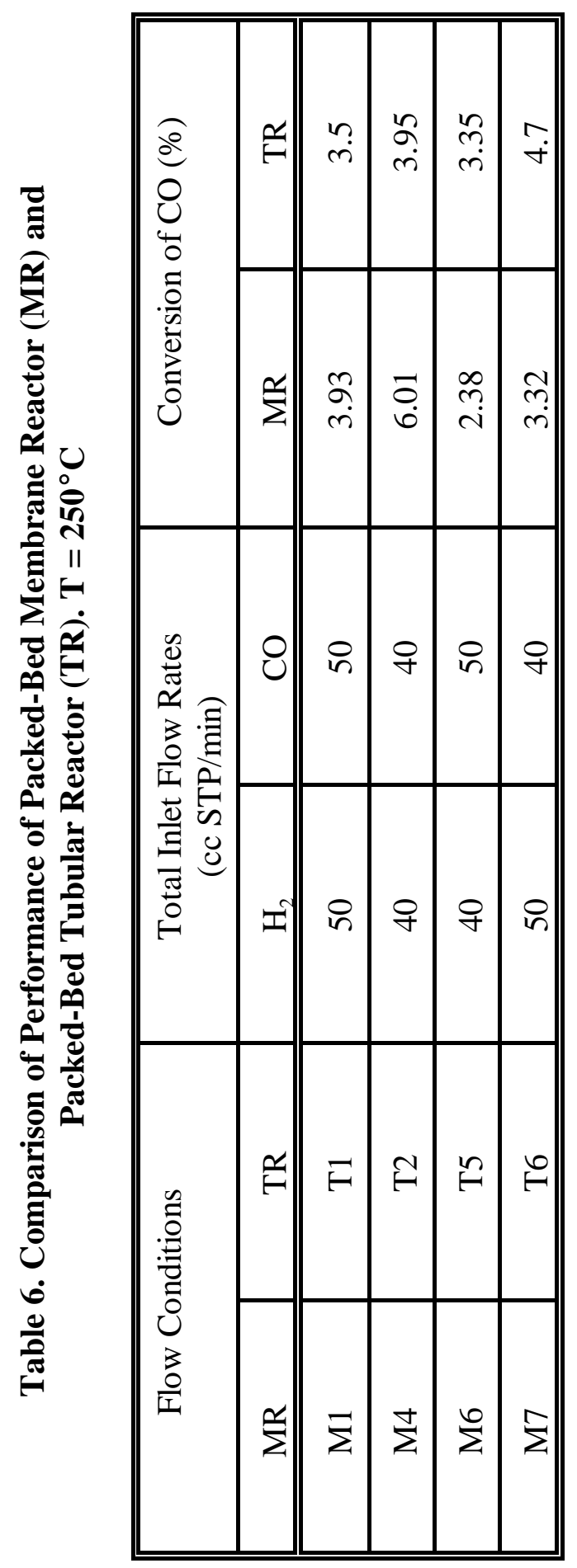

